\title{
A tax on currency transactions as an instrument in the war against poverty
}

\author{
John Williamson
}

$\mathrm{T}$

his paper considers whether a tax on currency transactions could be expected to raise a significant sum of money for use in the war on poverty. It traces the detailed discussion of Kenen and the subsequent argument of Schmidt, that technical developments would now permit the tax to be levied efficiently by the five authorities who issue currencies in which transactions are settled. It notes the creation of the CLS Bank and the proposal to confine a currency transactions tax to transactions that go through that bank, but argues that this would have dangers. It notes also Spahn's proposal for a geographically limited tax, but argues that this would not be advantageous if the aim is to raise revenue. The final verdict is that a currency transactions tax of 1 basis point would be feasible and could be expected to raise a sum of the order of US\$20 billion per year.

John Williamson Senior Fellow, Institute for International Economics, Washington, D.C.

• jwilliamson@iie.com 


\section{I}

\section{Introduction}

The idea of levying a "modest" tax on currency transactions goes back to a lecture that James Tobin, the Nobel Laureate in Economics, delivered in 1972. ${ }^{1}$ He envisaged a tax rate of perhaps $1 \%$ of the value of a foreign exchange transaction, which, he argued, might accomplish two purposes simultaneously. One would be to throw some sand in the wheels of international finance, which he envisaged as restoring a degree of independence to national monetary policies and curbing destructive destabilizing speculation. The second, a by-product, would be to raise money for some international good cause.

Subsequent debate has disputed these claims. The prospect of being able to stabilize the currency markets by taxing currency transactions is disputed by many, on the ground that instability is caused by the overhang of the stock of short-term assets rather than large flows of payments through the markets. Furthermore, many have claimed that a Tobin tax would be subject to such widespread evasion, through either the substitution of other transactions for those subject to the tax or the relocation of markets to untaxed jurisdictions, as to thwart the objective of giving a significant degree of independence to national monetary policies. Similarly, many dispute the idea that a tax rate of anything like $1 \%$ (100 basis points) ${ }^{2}$ could be levied without resulting in extensive evasion, arguing that it would probably lead to the existing dealer market being replaced by a broker market, which would shrink the volume of transactions enormously. One cannot estimate the yield of a currency transactions tax by taking $1 \%$ of the current value of such transactions (estimated at nearly US\$ 1.9 trillion per day in the latest survey by the Bank for International Settlements (BIS)) and conclude that it would be possible to raise trillions of dollars a year to finance some international good cause.

It may be infeasible to materially reduce the likelihood of currency crises by imposing a Tobin tax (though that is still subject to some dispute), but a relatively high tax rate (such as 25 basis points) might significantly widen international differences in monetary policies (Felix and Sau, 1996). Most relevant to the purpose of this group, and therefore to this note, even a very low tax rate could raise significant sums of money.

\section{II}

\section{Establishing a Tax Base}

A key condition that would have to be satisfied for a currency transactions tax to raise a substantial sum of money is the avoidance of significant evasion. A prerequisite for this is the establishment of an unambiguous and comprehensive tax base.

\footnotetext{
$\square$ This note was prepared for the Technical Group on Innovative Financing Mechanisms, and is published here with the consent of the Institute for International Economics (Copyright $($ ) Institute for International Economics. All rights reserved). The author is grateful to Ricardo Ffrench-Davis for his comments on an earlier draft.

${ }^{1}$ See Tobin 1974, amplified in Tobin 1978.
}

Currency transactions take a variety of forms. The plain vanilla operation is a spot transaction, where a holder exchanges (say) dollars for euros, for delivery today or tomorrow. The traditional alternative was a forward transaction, where a holder agreed a price at which he or she would buy (say) euros for dollars at some determinate date three days or more in the future. An exporter who knows he or she will be paid a foreign currency at some well-specified date in the future can hedge his or her receipts by selling the foreign currency

\footnotetext{
${ }^{2}$ One basis point is equivalent to one hundredth of a percentage point.
} 
forward on the date he or she will receive it, and buying his or her home currency with the proceeds. Covered interest arbitrage takes place by an agent selling dollars (say) for euros spot, investing for some defined period in euro-denominated assets, and then selling euros forward at the termination of the investment period, so that the operation has no currency risk. The more recent alternative is a swap transaction, where a holder of dollars (say) takes temporary possession of euros but with an agreement to reacquire the dollars at an agreed price at some specified date in the future and in the meantime allows the counterparty to make use of the dollar assets. The other major form of activity involves options, where a holder of dollars purchases a right to acquire euros (say) at a specified price, but exercises that right only if the market moves to a rate that yields a profit ("puts the contract in the money") within the period that the option holds. Yet another alternative is a futures contract, which is similar to a forward in that it promises delivery of a specified currency in return for another at a determinate exchange rate on a specified future date, but differs in that the contract can subsequently be traded on a public exchange. Futures are often settled merely by exchanging the net difference in value between the two currencies, and thus tend to appeal to those engaged in speculation rather than hedging of commercial transactions, but they would nevertheless be capable of providing a good substitute for a forward contract.

Tobin's initial suggestion was that a currency transactions tax (СТT) should apply just to spot transactions. He argued that this would catch most forward transactions too, because a bank that makes a forward sale of a currency typically covers itself by buying that currency spot. Even if this is normally true, however, it would probably not remain true for very long after the institution of a СTT. An untaxed threeday forward sale would be too good a substitute for a taxed two-day spot sale to prevent massive substitution of the former for the latter. ${ }^{3}$ Accordingly, subsequent writers have suggested broadening the tax base in order to catch all transactions that might provide good substitutes for spot transactions.

For a long time the most thorough and influential paper dealing with these issues was that by Peter Kenen

\footnotetext{
${ }^{3}$ Spot transactions are defined as those in which settlement is due within two days, and forward transactions as those in which settlement is due in three days or more. Even a modest tax rate would provide a strong incentive to postpone settlement by a day in normal times if that allowed avoidance of the tax.
}

(1996). Kenen proposed to levy the tax on forward transactions as well as on spot transactions, on the grounds presented above that these are very close substitutes and so imposition of the tax on just spot transactions would invite substitution of forwards. He suggested that one should tax futures as well, both when the contract was first struck and every time it was subsequently traded, since as also argued above these could easily emerge as good substitutes for forward transactions. Second, he proposed that the стт be extended also to swaps. This is because a swap provides a close substitute for the simultaneous spot and forward transactions that have customarily been involved in covered interest arbitrage, and they would therefore provide an efficient method for extensive tax avoidance if they remained untaxed. Third, he suggested that each party involved in a wholesale transaction (defined as one with another registered dealer, who would have to be just a dealer and not also acting as agent of a financial institution) should pay the tax at half the standard rate that would apply to retail transactions. Fourth, he proposed to base the tax on where deals are struck rather than where they are booked or settled, on the ground that dealing rooms are far more immobile than the computers used to book deals and that settlements are customarily made on net debts rather than the gross transactions that one would want to tax. Finally, and more relevant to the discussion in the next section, he proposed that transactions with noncooperating jurisdictions that did not levy the tax should be charged a penal rate, so as to discourage migration of dealing rooms to untaxed jurisdictions.

Kenen's most complex discussion concerns the advisability of taxing options. He acknowledged the danger that options left untaxed might start to crowd out forwards and futures, but was nevertheless reluctant to suggest taxing them. One reason is that an option may never be exercised, and another is that even if it is exercised the beneficiary will still have to buy foreign exchange spot (and will therefore pay the tax) if his purpose is hedging rather than speculation. He also argued that there was a danger of a tax on a "plain vanilla" options contract inspiring the "rocket scientists" to design synthetic currency contracts and more complex contracts, which would expose those who were induced to switch from forwards and futures to additional risks in dealing with complex derivative instruments.

Several other issues also concerned Kenen. First, he worried that his proposed structure involved assessing taxes solely on registered foreign exchange 
dealers, which would leave retail transactions between non-banks untaxed. While these may be small at the moment, there is a danger that they would rapidly grow if they were left untaxed and a substantial tax rate were imposed on transactions between dealers. Second, he suggested that "small" transactions (which he suggested might be defined as those of less than a million dollars each) be exempted. Third, he noted (but did not endorse) that many authors had taken for granted that official transactions, specifically those by currency boards, should be exempted. Finally, he noted that his structure would impose double taxation on those shifting between minor currencies, since a trade of (say) the Brazilian real for the Mexican peso is normally done by going through a vehicle currency (in practice the United States dollar) rather than directly.

Garber (1996) is one of the most influential sceptics of the feasibility of enforcing a стT. This is partly because of the difficulties discussed in the next section of establishing universal participation among governments, but he also argued that the market would be capable of devising ways of avoiding the tax. One channel he identifies is retail transactions between nonbanks: limiting these would in his view require bringing non-banks with active treasury departments into the tax net. Another avoidance technique would be possible if a foreign exchange transaction were defined as the exchange of one bank deposit for another in a different currency, since it would be possible to substitute swaps of treasury bills in countries with liquid treasury bill markets. Or else the two parties could provide credit to each other in the two currencies, collateralized by the claim that each has on the other. Yet other methods could be employed if supervisors and tax authorities saw through these subterfuges and began to tax them. Avoidance would end only when the liquidity premium on the less liquid assets that would be used was equal to the transactions tax.

Kenen's recommendation of levying a стт on the basis of where a deal is struck has been challenged by Schmidt (1999), whose argument has been endorsed by Clunies-Ross (2003). Schmidt argues that in view of technical developments since Kenen's paper it would now be feasible for the monetary authorities that issue the world's five vehicle currencies ${ }^{4}$ to identify and therefore to tax the gross value of all transactions into

\footnotetext{
${ }^{4}$ The United States dollar, euro, yen, pound sterling, and Swiss franc.
}

and out of their currencies. This would involve the tax being collected by the authorities in which transactions are settled rather than agreed. Kenen dismissed this possibility on the ground that many transactions are netted before they are settled, but Schmidt argued that the monetary authorities of the vehicle-currency countries have the leverage needed to oblige offshore netting systems, as well as their own foreign exchange banks, to report gross transactions to them. This is possible because of arrangements that have already been adopted in order to protect transactors against settlement risk. In fact monetary authorities already levy charges on bank settlements of currency transactions in order to pay for use of the information software used in settlement, and since all transactions go through one of the five vehicle currencies at least once it would need only those five authorities to collect the cTT.

An agreement that involved only those five authorities would be subject to the danger of avoidance as banks shifted their operations to other currencies. To safeguard against this, Schmidt suggests that another eight or so countries with currencies that might come to be used as vehicle currencies would need to be prepared to cooperate in applying the tax if migration of the market were to occur. It would be desirable to obtain their ex ante agreement, so as to discourage market migration induced by the hope of tax avoidance.

It has been claimed that the feasibility of levying the tax at the settlement stage has been further enhanced by the opening in September 2002 of the CLs Bank. ${ }^{5}$ "CLS" stands for "continuous linked system" and is a private sector response to the Group of Ten's concern with settlement risk. Under the traditional foreign exchange system, all foreign exchange trades due to be settled in a particular centre on a particular day were settled simultaneously at the end of that centre's working day. Since many foreign exchange trades involved more than one time zone, this exposed traders to the risk that they would not receive their payment

\footnotetext{
${ }^{5}$ The parent company is Swiss while the operational bank is in London. Both are regulated by the Federal Reserve. The holding company has 71 shareholders, and they and another 257 third parties settle their transactions in the 15 currencies currently covered by the system through the central banks of the countries involved (the issuers of the 5 vehicle currencies plus Australia, Canada, Denmark, Hong Kong SAR, New Zealand, Norway, Republic of Korea, Singapore, South Africa and Sweden).
} 
because their counterparty would become insolvent in the interim (like Herstatt Bank in September 1974). The cLs Bank enables those who use it to avoid this risk, because the payment in one currency (the one that has been sold) occurs simultaneously with receipt of the other (the one that has been bought): the CLS Bank operates 24 hours a day on the basis of continuous clearing. The CLS is now estimated to have a turnover of about US\$ 1 trillion a day, which is reported to be about $45 \%$ of current market volume.

One possibility would be to confine a currency transactions tax (СтT) to those transactions that go through the CLS. This would mean sacrificing over half of the yield of the tax, at least on present parameters. There is also an issue as to how many transactions would be diverted from the CLS if it alone were to be subjected to a tax. Obviously this would depend on the rate of tax, but even with a very low rate that possibility should be borne in mind. Presumably a member bank or registered third party is not obliged to channel all its transactions through the CLS Bank, in which case one might expect that many participants would react to a Стт by settling their routine transactions (those with highly creditworthy partners in normal times and the same time zone) outside the CLS system.

\section{III}

\section{Governmental Participation}

It has long been argued that it would be essential to operation of a CTT to have the participation of all countries with active foreign exchange markets. The reason is that non-participation by even one centre would give it an enormous competitive advantage, so that the market would rapidly migrate to that centre and undermine the tax regime. Not only is this true of established financial centres, including the ones like Hong Kong SAR and Singapore in economies that have not traditionally been classified as industrial countries, but it is argued that the market would migrate to putative financial centres like Grand Cayman or the Bahamas if they did not levy the tax. Even gaining the adhesion of the traditional financial centres like London and New York would be problematic, given that the United Kingdom and the United States have for many years taken a very laissez-faire line on their offshore financial sectors, in part motivated by the rich financial pickings from hosting such a sector. The usual conclusion has been that general participation is doubly necessary: both in order to prevent the market migrating and the tax being undermined by that migration, and to reassure the market leaders that their position would not be undercut by any such migration occurring.

The paper of Kenen (1996) already discussed in the previous section made an important proposal that might make this challenge somewhat less demanding. If the agreement establishing a СтT were to include his suggestion of a penal rate $^{6}$ on transactions with jurisdictions that did not levy the стT, this would probably make it necessary only to reach agreement among the countries that already have established financial centres, and not to get every potential tax haven like Grand Cayman and the Isle of Man on board too. But that leaves a demanding task: One is talking not only about the United States and the United Kingdom, about Hong Kong SAR and Singapore, but also about countries like Chile, South Africa and New Zealand where the foreign exchange market currently serves only local needs but could easily be expanded to deal also with dollar/euro and dollar/yen trade. On the other hand, levying the tax by the place of settlement as urged by Schmidt would be far less demanding.

An important paper by Spahn (2002) has challenged the conventional view that the tax makes sense only if imposed universally. Spahn argues that it would be feasible for the European Union to tax transactions involving the euro (and the pound sterling?) at a modest rate even if other issuers of vehicle currencies (except perhaps for Switzerland) declined to cooperate. His argument about the need for Swiss cooperation seems to rest on the tax being levied on deals agreed by trading desks (as suggested by Kenen), since it is based on the strong advantages to the trading centres being in the same

\footnotetext{
${ }^{6} \mathrm{He}$ suggested a rate a hundred times higher, of $5 \%$ rather than $0.05 \%$.
} 
time zones as those where trades are generated. However, this option would generate cumbersome reporting requirements, which are largely unnecessary if one resorts to the alternative espoused by Schmidt, of relating the tax to settlement. Under the option of automated, centralized tax collection at the stage of settlement, tax liability arises from the access of market participants to national gross settlement systems. Operations prior to settlement (such as the taxation of forward transactions espoused earlier) can be included by contractual requirements on those participating. Spahn argues that there would still be a need for reporting by institutions (including big multinational companies that settle many trades internally) that do not participate in official and centralized clearing and settlement. These institutions could either join the official system or convey relevant information to it.

If one is looking to maximize the revenue yielded by a стт, then a geographically limited tax such as that espoused by Spahn makes little sense. Only if the issuer of one or more of the vehicle currencies were adamantly opposed to even a very modest rate of стт while the others were favourable would it make any sense to contemplate this. But one should not have any illusions that there would be potentially important effects from even a low tax rate. For example, the euro's role as a vehicle currency between (say) Poland and the Czech Republic would surely fall victim to a стт that was imposed by the European Union but not by the United States.

\section{IV}

\section{Revenue-Raising Potential}

How much money could a cTT raise? That depends upon the design of the tax and the rate at which it is imposed. There are of course many possibilities, but it is notable that over time the tax rates that have been discussed have fallen dramatically. Tobin initially spoke of a $1 \%$ rate, but in 1995 he wrote that a $0.1 \%$ tax rate might be more prudent to avoid swamping the normal commission (Tobin 1996). At the same conference Jeffrey Frankel also spoke of a $0.1 \%$ rate, and Peter Kenen of $0.05 \%$, while only Stephany Griffith-Jones $(0.5 \%)$ and David Felix and Ranjau Sau $(0.25 \%)$ suggested tax rates higher than Tobin's figure. Since then Nissanke (2005) has estimated the revenue that would be raised by tax rates of $0.01 \%$ and $0.02 \%$ (respectively 1 and 2 basis points), while Spahn (2002) suggested tax rates of 0.01 and $0.005 \%$ (respectively one basis point and half a basis point).

The most optimistic revenue estimates assume high tax rates and minimal impact of the tax in reducing the volume of transactions. As an extreme case, consider the yield of a $1 \%$ (100 basis points) tax rate on foreign exchange turnover of US\$ 1.88 trillion per day (the BIS estimate of turnover in April 2004, after netting out for double counting), assuming that there were no evasion and no decline in foreign exchange market activity induced by the tax. Such a CTT would raise nearly US\$ 19 billion a day, or US\$ 4.5 trillion per year, assuming 240 working days in a year. However, in view of the previous discussion of the difficulties of establishing an erosion-resistant tax base and the fact that a tax rate this high would yield many thousands per cent of the traders' value added, it is fanciful to imagine that a СТT could yield anything of this order of magnitude.

Hypothesize instead a tax imposed at an equal rate on all spot foreign exchange transactions, as Tobin initially did, but at a rate typical of other indirect taxes. VAT, for example, is typically something in the vicinity of $15 \%$. The value added in a foreign exchange transaction-the margin between buying and selling rates-is reported by Spahn to be only around one basis point for large inter-dealer wholesale transactions (what is often referred to as "hot potato trading"), which still constitute the majority of transactions. ${ }^{7}$ That would suggest that the tax rate might be around 0.15 basis points in order to impose a burden comparable to other indirect taxes. That may not sound much, and certainly not compared to Tobin's initial suggestion of 100 basis points, but $0.0015 \%$ of US\$ 621 billion (the latest BIS estimate of the daily value of spot transactions) is over

\footnotetext{
${ }^{7}$ The latest BIS survey estimated that about $53 \%$ of foreign exchange transactions were purely between dealers. This marks a considerable decline from the 59\% reported in 2001 and the $70 \%$ reported in 1992 .
} 
US\$ 9 million. Given 240 working days in a year, a CTT at this rate would yield around US\$ 2.2 billion per year if there were no evasion and no decline in foreign exchange market activity induced by the tax. Unless that decline were more than $10 \%$, a currency transactions tax could be expected to raise over US\$ 2 billion a year in the absence of evasion. That is modest compared to the estimates that have usually been presented, but perhaps still enough to make the tax worth consideration. The cost of administration of the tax, which no one seems to have estimated, would need to be deducted, but this would presumably be rather small as the tax could be levied automatically by suitable programming of the computers used in the forex market, especially if the tax were assessed on settlement rather than deals.

There is a big gap separating US\$ 4.5 trillion and US\$ 2 billion. Is it possible to envisage a cTT that could realistically be expected to yield more than the latter sum?

How about levying the tax on the base and at the rates proposed by Kenen (1996)? This would tax forward and swap transactions as well as spot transactions, at a standard tax rate of 5 basis points and with a tax on inter-dealer transactions that would be $2 \frac{1}{2}$ basis points each. Given the BIs estimate of US\$ 1,880 billion turnover per day, this tax would yield US\$ 940 million per working day or US\$ 226 billion per year, in the absence of evasion and any tax-induced decline in foreign exchange market activity. If each final transaction involves one inter-dealer transaction as well, the cost of a final transaction would increase by 10 basis points, or maybe by $100 \%$. (Margins with final consumers are of course far bigger than the interdealer margins referred to before.) If the demand for final foreign exchange transactions has unitary elasticity, the doubling of cost would imply a halving in the volume of foreign exchange transactions and therefore in tax revenue, to US\$ 113 billion per year, which is still a substantial sum.

With a rate as high as this, however, one has to worry about the qualifications concerning evasion and an induced decline in market activity. On inter-dealer transactions the tax rate would be about $250 \%$ of value added, which is the sort of tax rate that customarily induces strong efforts at avoidance. If the doomsday scenario -in which the tax induces collapse of the existing dealer structure of the market in favour of a structure in which foreign exchange brokers put customers directly in contact with one another- were to materialize, the tax base would shrink by at least
$53 \%$ (the latest estimate of the proportion of transactions that are hot-potato inter-dealer transactions). Admittedly in that event the cost of a final transaction might rise by something short of 10 basis points, so the potential tax yield might be over US\$ 53 billion per year (which is $47 \%$ of US\$ 113 billion), perhaps in the range of US\$ 60 billion to US\$ 100 billion per year.

If one worries that Kenen's proposed rates are too high, a possible compromise would be to adopt his suggestions regarding the tax base but to adopt a tax rate of one basis point (and thus half a basis point each for inter-dealer transactions), as several other writers have discussed. This would yield $0.01 \%$ of US $\$ 1.88$ trillion for 240 days a year, or some US $\$ 45$ billion per year in the absence of evasion and any decline in foreign exchange market activity induced by the tax. ${ }^{8}$ Of course, one should expect that the tax would induce some decline in market activity. Again assuming that each transaction with a final consumer induced one inter-dealer transaction as well, whose cost is passed on, and unit elasticity of the demand curve for foreign exchange transactions by final consumers, the estimated yield of a currency transactions tax would be some US\$ 23 billion per year, without allowing for collection costs.

Lastly, consider finally the potential yield of a tax confined to transactions through CLS, which are stated to total about US\$ 1 trillion per day, so a 1 basis point tax rate would yield some US\$100 million per day or US $\$ 24$ billion per year, without evasion or any impact on trading volume; the latter would probably result in a tax yield of well under US\$20 billion a year.

These figures may be compared to those that have been advanced by other recent writers, as shown in the box.

\footnotetext{
${ }^{8}$ Is this figure compatible with the US\$ 2 billion per year previously cited for a 0.15 basis point tax on spot transactions? Yes. Spot transactions are less than a third of the transactions that Kenen proposes to tax, and 0.15 basis points (the tax rate) is little more than one-seventh of the tax rate postulated here.
} 

Some writers have tried to argue that the incidence of such a tax would probably be progressive, either because it would squeeze the financial sector or because the main users of the currency markets tend to be the wealthy. In my view the operative word here is "probably". We really do not have the evidence to conclude a strong presumption about the distributive impact of a СтT, but I would concur in the presumption that it is likely to be progressive.

\section{Bibliography}

Clunies Ross, A. (2003): Resources for Social Development, Working Paper, No. 21, Geneva, World Commission on the Social Dimension of Globalization, International Labour Organization (ILO).

Felix, D. and R. Sau (1996): On the revenue potential and phasing in of the Tobin tax, in M. ul Haq, I. Kaul and I. Grunberg (eds.), The Tobin Tax: Coping with Financial Volatility, New York, Oxford University Press.

Frankel, J. (1996): How well do markets work: might a Tobin tax help?, in M. ul Haq, I. Kaul and I. Grunberg (eds.), The Tobin Tax: Coping with Financial Volatility, New York, Oxford University Press.

Garber, P.M. (1996): Issues of enforcement and evasion in a tax on foreign exchange transactions, in M. ul Haq, I. Kaul and I. Grunberg (eds.), The Tobin Tax: Coping with Financial Volatility, New York, Oxford University Press.

Griffith-Jones, S. (1996): Institutional arrangements for an international tax on currency transactions, in M. ul Haq, I. Kaul and I. Grunberg (eds.), The Tobin Tax: Coping with Financial Volatility, New York, Oxford University Press.

Kenen, P.B. (1996): The feasibility of taxing foreign exchange transactions, in M. ul Haq, I. Kaul and I. Grunberg (eds.),
The Tobin Tax: Coping with Financial Volatility, New York, Oxford University Press.

Nissanke, M. (2005): Revenue potential of the Tobin tax for development finance: a critical appraisal, in A.B. Atkinson (ed.), New Sources of Development Finance, Oxford, Oxford University Press.

Schmidt, R. (1999): A Feasible Foreign Exchange Transactions Tax, Ottawa, The North-South Institute, June.

Spahn, P.B. (2002): On the Feasibility of a Tax on Foreign Exchange Transactions, Bonn, Federal Ministry for Economic Cooperation and Development. Available in www.wiwi.uni-frankfurt.de/professoren/spahn/tobintax.

Tobin, J. (1974): The New Economics One Decade Older, Princeton, Princeton University Press.

(1978): A proposal for monetary reform, Eastern Economic Journal, vol. 4, No. 3/4, Middletown, Connecticut, Eastern Economic Association, July-October. (1996): Prologue, in M. ul Haq, I. Kaul and I. Grunberg (eds.), The Tobin Tax: Coping with Financial Volatility, New York, Oxford University Press. 